уДК 666.6

\title{
ВИКОРИСТАННЯ ВІДХОДІВ ДЕРЕВООБРОБНОЇ ПРОМИСЛОВОСТІ В КЕРАМІЧНІЙ ТЕХНОЛОГІї
}

\author{
А.С. Шолом, І.С. Суббота, Л.М. Спасьонова \\ Начіональний технічний університет Украӥни \\ «Київський політехнічний інститут ім. Ігоря Сікорського» \\ пр. Перемоги, 37, Київ, 03056, Україна \\ e-mail: anastasia14.sholom@gmail.com
}

Стрімкі темпи зростання обсягів виробництв та їх розвиток призвели до накопичення в навколишньому середовищі великотоннажних промислових і сільськогосподарських відходів. Їх утилізація сприяє розширенню сировинної бази керамічної промисловості, є економічно ефективною і спрямованою на вирішення екологічних та соціальних проблем. Тому використанню відходів у технології керамічних будівельних матеріалів приділяють велику увагу [1].

Застосування вторинної сировини дає можливість зменшити споживання мінеральносировинних ресурсів і знизити собівартість готової продукції, бо відходи у 2-3 рази дешевше природної сировини для керамічного виробництва. При цьому необхідне підтвердження відповідності безпеки й фізико-механічних властивостей такої продукції чинним стандартам [2].

Екологічно та науково важливим є використання відходів деревообробної промисловості, таких як деревна тирса i деревна зола, відходи целюлозно-паперового та цукрового виробництва. Їх утилізація можлива завдяки тому, що вони відносяться до V класу небезпеки забруднюючих речовин і є безпечними. Такі відходи не містять у своєму складі токсичних речовин і не становлять загрози для довкілля, здоров'я та життєдіяльності людини [3]. У керамічній технології вони використовуються в якості пороутворюючої складової для отримання легких за масою виробів. Такі добавки під час випалу виділяють $\mathrm{CO}_{2}$, що, у свою чергу, сприяє економії енергії та утворенню пор в керамічному черепку.

Необхідно досліджувати вплив включення відходів деревообробної промисловості у виробництво на характеристики міцності керамічних матеріалів, отриманих у такий спосіб. Це дозволить при подальших прикладних дослідженнях підібрати їх допустимий вміст в сировині, оптимальну дисперсність і параметри випалу для створення конкурентоспроможної якісної керамічної продукції.

Основна мета дослідження - простежити вплив дисперсності добавки, що вигорає, на механічні характеристики отриманих зразків на основі сировини різної тонкості (менше 1- 
0,5 мм) при різній температурі випалу $\left(950-1050{ }^{\circ} \mathrm{C}\right)$ для створення оптимального співвідношення розміру частинок.

У дослідженні використовували легкоплавку, помірно пластичну глину Київської області (Україна) [4]. Тирса деревообробного підприємства вводилася в масу у вигляді добавки, що вигорає, в кількості до 10 \%. Формування зразків проводили напівсухим способом (при тиску 15 МПа). Для визначення показників міцності при стисненні використовували стандартні методики, описані в [5].

Вивчали вплив дисперсності пороутворюючої добавки (тирса) на механічні характеристики виробу при різних температурах випалу. На рисунку 1 представлена міцність зразків на стиск в залежності від дисперсності добавки і температури випалу при діаметрі частинок сировини менше 1 мм.

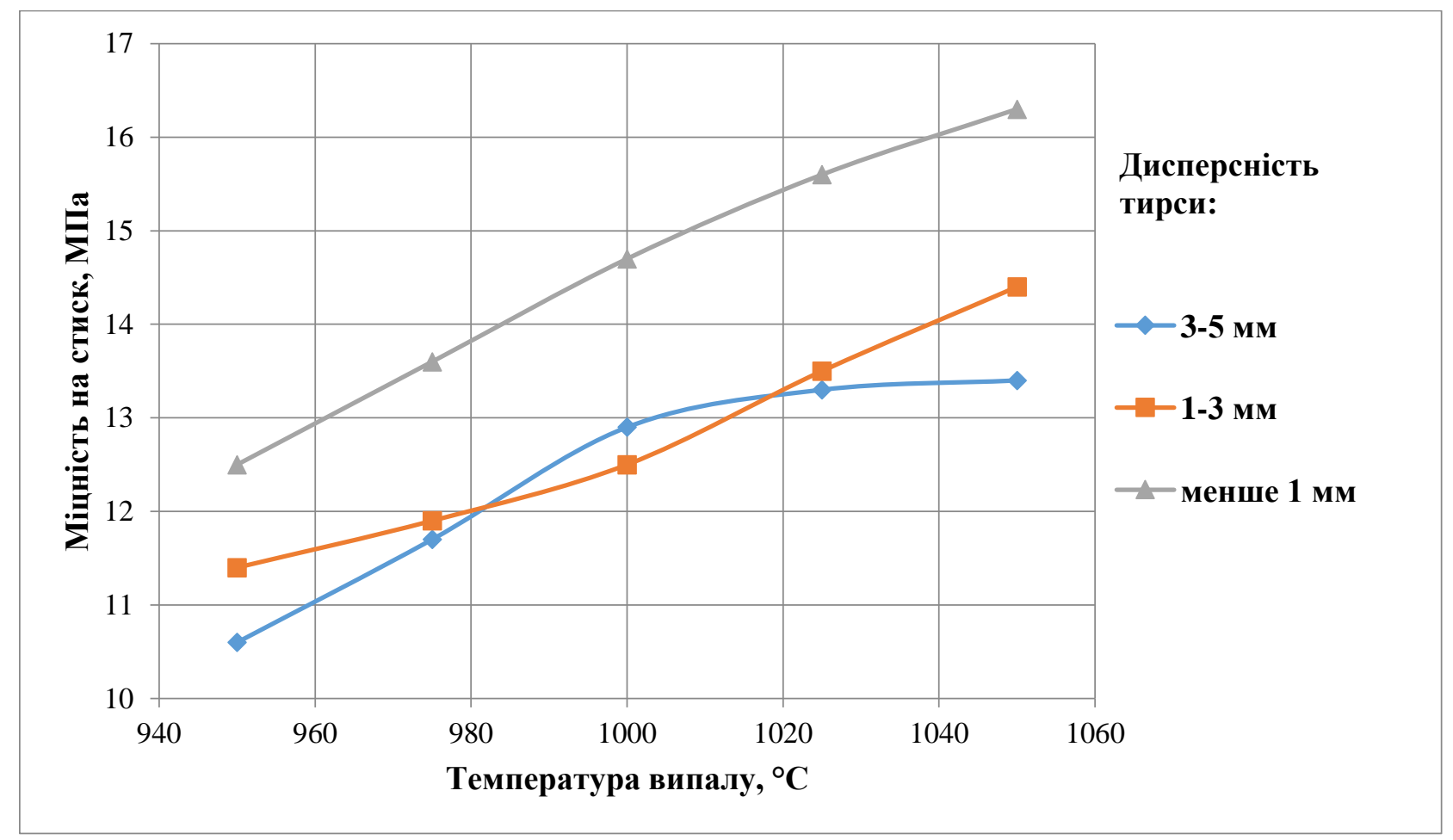

Рисунок 1. Міцність зразків на стиск в залежності від дисперсності добавки, що вигорас, і температури випалу

Аналіз отриманих результатів показав, що кращі результати міцності для діаметра частинок сировини демонструють зразки з частинками розміру менше 1 мм. Співвідношення дисперсності сировини і добавки з відходів 1:1.

Результати вивчення міцності в залежності від температури випалу і розміру частинок пороутворюючої добавки при величині дисперсності вихідної сировини 0,8 мм представлені на рисунку 2. 
Матеріали XXII Міжнародної науково-практичної конференції «Екологія. Людина. Суспільство» (м. Київ, Україна, 2021 р.)



Рисунок 2. Міцність зразків на стиск в залежності від дисперсності добавки, що вигорає, і температури випалу

Отже, для вихідної сировини, діаметр частинок якої становить 0,8 мм, вищі показники міцності на стиск при дисперсності тирси 1-3 мм. Оптимальне співвідношення дисперсності: $1: 0,7$.

На рисунку 3 представлені результати дослідження впливу розміру частинок добавки, що вигорає, на основі відходів в залежності від температури випалу при дисперсності вихідної маси менше 0,5 мм.



Рисунок 3. Міцність зразків на стиск в залежності від дисперсності добавки, що вигорає, і температури випалу 
Для керамічної сировини, розміром частинок менше 0,5 мм, дисперсність тирси для вищого значення міцності на стиск складає менше 1 мм.

Дослідження показали, що збільшення дисперсності добавок, що вигорають (від 5 до менше 1 мм), і температури випалу (від 950 до $1050^{\circ} \mathrm{C}$ ) зразків зменшують розміри пор черепку, що призводить до зменшення щільності і зміни міцності (в середньому від 6 до 14 МПа). Можна зробити висновок, що зі збільшенням дисперсності добавки, що вигорає, 3 відходів деревообробки зростає міцність обпаленого керамічного матеріалу.

Найкращий показник міцності (16,3 МПа) має матеріал із $10 \%$ вмістом добавки тирси дисперсністю до 1 мм при температурі випалу $1050{ }^{\circ} \mathrm{C}$, діаметр частинок природної глинистої сировини до 1 мм. Результати проведених досліджень показали, що оптимальна міцність зразків досягається при використанні сировинної суміші і добавок, що вигорають, однакової дисперсності (співвідношення розміру частинок 1:1). Це пояснюється однорідністю отриманої маси, що сприяє створенню більш міцних зв'язків в результаті фізико-хімічної взаємодії процесу отримання керамічних виробів.

Міцність зразків з включеними відходами деревообробних підприємств (до 16,3 МПа) не поступаються виробам з виключно природної сировини (без тирси міцність на стиск будівельної кераміки становить від 7,5 до 35 МПа). Вироби 3 такими добавками мають перевагу завдяки зменшенню використання енергії на випал. Підвищена пористість забезпечує зменшення маси виробу (до $5 \%$ ), що значно покращує характеристики певних видів керамічної продукції Це дає підстави продовжувати вдосконалення керамічної технології 3 використанням відходів, зокрема відходів деревообробки.

\section{Література:}

1. Использование отходов в производстве керамики [Електронний ресурс]. - Ярославская областная научная библиотека имени Н.А. Некрасова, 2018 - Режим доступу: http://www.rlib.yar.ru/index.php?option=com_content\&task=view\&id=3133\&Itemid=380.

2. Z.U. Elakhame, Y.L. Shuaib-Babata, I.O. Ambali. Development and evaluation of ceramic tiles using wastes and solid minerals, Journal of Engineering Research, 16(1), pp. 53-62, 2019, doi: 10.24200/tjer.vol16iss1pp53-62.

3. L.V. Popova, P.S. Repin, V.I. Korchagin, R.N. Plotnikova, Using the Method of Phyto-testing to Determine the Hazard Class of Waste, Ecology and Industry of Russia 23(9), pp. 49-53, 2019, doi: 10.18412/1816-0395-2019-9-49-53.

4. L. Spasonova, I. Subota, A. Sholom, Devising technology for utilizing water treatment waste to produce ceramic building materials, Eastern-European Journal of Enterprise Technologies, №1/10 (109), pp. 14-22, 2021, doi: 10.15587/1729-4061.2021.225256.

5. Практикум по технологии керамики. Учебное пособие для ВУЗов / Под ред. проф. И.Я. Гузмана. - М.: ООО РИФ «Стройматериалы», 2005.-334с. 